\title{
Early Induction of ADAMTS1, $-4,-5$ and -9 in IL-Stimulated Mouse Astrocytes
}

\author{
Interlökin-Stimüle Edilmiş Fare Astrositlerinde ADAMTS1, -4, -5 ve -9 \\ Genlerinin Erken Dönemde Indüklenmesi
}

Osman ABALI ${ }^{1}$, Emre Cemal GOKCE², Berker CEMIL ${ }^{2}$, Bulent ERDOGAN ${ }^{2}$, Tomoko YONEZAWA², Kadir DEMIRCAN ${ }^{4}$

${ }^{1}$ Istanbul Univetsity, School of Medicine, Department of Child and Adolescent Psychiatry, Istanbul, Turkey

${ }^{2}$ Turgut Ozal University, School of Medicine, Department of Neurosurgery, Ankara, Turkey

${ }^{3}$ Okayama University, Graduate School of Medicine and Dentistry, Department of Molecular Biology and Biochemistry, Okayama, Japan

${ }_{4}^{4}$ Turgut Ozal University, School of Medicine, Department of Medical Biology, Ankara, Turkey

Corresponding Author: Osman ABALI / E-mail: osmanabal@hotmail.com

\begin{abstract}
AIM: Astrocytes and extracellular matrix molecules have important roles in regulating synaptic functions between neurons in the central nervous system. However, under pathological conditions, these constituents are activated to form glial scar that is thought to be harmful for neuronal regeneration. The aim of this study was to evaluate the expression pattern of ADAMTS1, $-4,-5$ and -9 in IL-1 stimulated astrocyte cultures obtained from postnatal day zero mouse brains.
\end{abstract}

MATERIAL and METHODS: Real time PCR analyses were performed.

RESULTS: An overexpression of ADAMTS1, $-4,-5$ and -9 at the 3-h time point after IL-1 stimulation was found. IL-1 stimulation induced aggrecaneses and this effect was time dependent. Maximum increase was detected at 3-h (six fold increase). Interestingly the expression of ADAMTS1 and -4 appeared to be at the highest expression level but the ADAMTS5 and ADAMTS9 expression level was much weaker (three times and two times respectively).

CONCLUSION:To the best of our knowledge, this is the first report demonstrating induction of ADAMTS in IL-1 induced astrocytes. Aggrecanases may play a role in tissue destruction in the progression of central nervous system (CNS) injury and they are differentially expressed in mouse CNS, suggesting a critical role in the pathogenesis of CNS injury. This can be a very crucial aetiologic factor for some neuropsychiatric disorders.

KEYWORDS: Astrocyte, Extracellular matrix proteins, ADAMTS, Neuronal regeneration

öz

AMAÇ: Nöronlar arasındaki sinaptik fonksiyonların düzenlenmesinde astrositler ve ekstrasellüler matriks proteinlerinin çok önemli rolü bulunmaktadır. Ancak travma, inme ve nörodejeneratif hastalıklar gibi çeşitli patolojik durumlar astrositlerin nöral rejenerasyon üzerinde engelleyici ve zararlı etkileri olan glial skar dokusu oluşturmaküzere aktive olmalarına neden olmaktadır. Bu durum aynı zamanda astrositlerden ekstrasellüler matriks komponentlerinin yıkımından da sorumlu olan metalloproteinazların salınımına da yol açmaktadır. Çalışmamızda, postnatal 0 . günde alınan fare beyinlerinden elde edilen normal ve IL-1 ile stimüle edilmiş astrosit kültürlerinde ADAMTS1, $-4,-5$ ve -9 gen ekspresyon düzeyleri arasındaki korelasyonu değerlendirmeyi amaçladık.

YÖNTEM ve GEREÇLER: Gerçek zamanlı polimerize zincir reaksiyonu analizi kullanıldı.

BULGULAR: IL-1 ile stimüle edilmiş astrosit kültürlerinde 3. saatte ADAMTS1, $-4,-5$ ve -9 salınımlarının kontrol grubuna göre artmış olduğu görüldü. IL stimülasyonu zamana bağlı olarak bütün agrekanazların artmasına sebep oldu. Maksimum artış 3 saat sonra görüldü. ADAMTS1 ve -4 'te en yüksek ekspresyon izlendi. Bununla birlikte ADAMTS5 ve -9 ekspresyonu daha zayıf kaldı.

SONUÇ: Agrekanazlar, merkezi sinir sistemi (MSS) patolojilerinde ve hasarlarında, ekstraselüler matriks yıkım ve yeniden yapılanmasında rol oynamaktadır. ADAMTS'ler MSS patolojilerinde yeni bir gen grubu olabilirler, bazı nöropsikiyatrik ve nörodejeneratif hastalıkların patoetiyolojisinde rol alabilirler.

ANAHTAR SÖZCÜKLER: Astrosit, Ekstraselüler matriks proteinleri, ADAMTS, Nöronal rejenerasyon

\section{INTRODUCTION}

Astrocytes, the major glial cell type in the central nervous system, are largely responsible for development and maintenance of central nervous system. However, pathologic entities such as injury of CNS with trauma, stroke and neurodegenerative disease stimulate and activate glial cells, in particular astrocytes to release growth factor and increase the expression of extracellular matrix (ECM) molecules to form glial scar tissue (18). These pathological process impede regeneration and regrowth of axons into the injured site. It seems that overcoming glial scar formation may be a promising approach to repair severed connections of the central nervous system. 
Chondroitin sulphate proteoglycans (CSPGs) such as aggrecan, brevican, neurocan, phosphacan and versican are the ECM molecules in the brain and they are essential molecules for brain structure and function (6) (23). CSPGs consisting of a core protein and adhered sulfated glycosaminoglycan (GAG) chains are also known to be upregulated in response to injury secondary to astrocyte activation and this prominent chemical constituent is rich in glial scar (2).

A new class of metalloproteinases comprising matrix metalloproteinases (MMPs), ADAMs (a disintegrin and metalloproteinase domain) and ADAMTS (a disintegrin and metalloproteinase with thrombospondin type 1 motifs) families have complex roles in normal development and pathological conditions (4). ADAMTSs are a group of recently described secreted molecules encoded by 19 identified genes in human (19). From the time the ADAMTS proteainases have been identified, they are known to be altered in a variety of biological processes such as angiogenesis, cancer, blood coagulation, cell migration and arthritis and these gene families have encouraged the researchers to study in different areas. ECM molecules are potential substrates for ADAMTSs, and ADAMTSs are likely to be involved in modulation of CSPGs due to their substrate specificities.

Though it is known that MMPs contribute to neuroinflammation in the CNS by degrading basal lamina and disrupting blood brain barrier, less is known regarding the functions of ADAMTSs in the CNS. This study highlights the expression analysis of ADAMTS-1, $-4,-5$ and -9 mRNAs by real time PCR in normal cultured astrocytes and in IL-1stimulated ones. To our best knowledge, this report is the first demonstration of ADAMTS stimulation in IL-1 induced astrocytes.

\section{MATERIAL and METHODS}

\section{Primary Astrocytes}

Eight primary mouse astrocytes were obtained from postnatal day 0 mouse brains and were cultured in serum-free DMEM/F-12 supplemented with $10 \%$ FBS, $100 \mathrm{U} / \mathrm{ml}$ penicillin, and $100 \mathrm{mg} / \mathrm{ml}$ streptomycin, culturing in a humidified atmosphere with $5 \% \mathrm{CO}_{2}$ at $37^{\circ} \mathrm{C}$ in the presence and absence of IL-1beta.

\section{Total RNA Isolation and Real Time PCR}

Total RNA extracted from cultured astrocytes was reversely transcribed to complementary DNA (cDNA) with random primers and then real-time polymerase chain reaction (realtime P(R) was performed on CDNA samples. Mouse $\beta$-actin was amplified as a control for the PCR. Quantitative real time PCR was performed using a LightCycler rapid thermal cycler system (Roche) described previously $(3,9,10,14,25)$. Mouse primers for PCR were designed to amplify fragments for each ADAMTS gene and $\beta$-actin. PCR products were separated by electrophoresis and visualized in $1.5 \%$ agarose gels with ethidium bromide. Data were presented as means 6 SEM of independent experiments using cells derived from different batches of mouse. Statistical analysis was performed via ANOVA. $\mathrm{P}<0.05$ was considered statistically significant.

\section{RESULTS}

Our data revealed that astrocyte cultures constitutively released ADAMTS1, $-4,-5$ and -9 . The quantitative expression of mRNA for ADAMTS1, $-4,-5$ and -9 were studied by real time PCR in cultured astrocyte. $10 \mathrm{ng} / \mathrm{ml} \mathrm{IL-1beta} \mathrm{was} \mathrm{applied} \mathrm{to}$ the astrocyte cultures, and the expression levels of ADAMTSs were analyzed at 3, 12 and 24 hours time points. The quantitative analysis showed that IL-1 stimulation induced all aggrecaneses (studied in this study) and this effect was time-dependent. Maximum increment was detected at 3-h time point (six fold increase for ADAMTS1, five fold increase for ADAMTS4, three fold increase for ADAMTS5 and two fold increase for ADAMTS9). Interestingly the expression of ADAMTS1, and ADAMTS4 appeared to be at the highest expression level (Figure 1), but ADAMTS5 and ADAMTS9 expression level was much weaker than others (Figure 1). The $p$ value was significant compared to control group. The levels of aggrecaneses were detected to be returned to basal levels at 12 and 24 hours time point. There was no significant difference in the expression levels between normal and IL-1 stimulated cultures at 24 hours.

\section{DISCUSSION}

Here, we showed for the first time, early overexpression of ADAMTS1, $-4,-5$ and -9 after IL- 1 stimulation in astrocytes. This early time-dependent induction (two to six fold) may infer ADAMTS as a candidate player of CNS pathophysiology.

Glial scarring, composed of reactive astrocytes and ECM molecules constitute an obstacle which inhibits axonal regeneration, thus designates the course of the disease (16). Astrocytes formerly known as a'glue'existing between neurons, are yet to be recognized for performing very important functions such as regulation of synaptic organization, maturation and development of CNS (17). However, when an injury insults the CNS, astrocytes are activated to release inflammatory cytokines and form a glial scar, causing the enhancement of CSPGs expression and finally act as a barrier to regenerating neurons (21). This pathological process that astrocytes undergo after injury is known as 'reactive gliosis' and results in an increase in the injured area size, cell death, an exacerbated immune response and marked motor deficits (7). Proteoglycans are a primary and abundant component of the brain extracellular environment. A core protein and adhered high levels of sulfated glycosaminoglycan (GAG) chains form this constituent (22). The core protein contains 3 globular and 1 interglobular domains as G1, G2, IGD, and G3, respectively. Varying numbers and lengths of GAG chains that are bound to the core protein identify the differentiation (9). After being modified in the golgi apparatus post translationally, they exist attached to the membrane via a transmembrane domain or a GPI-link or secreted. Proteoglycans play crucial roles in normal development such as regulation of cell signalling pathways, arranging cell-microenvironment interactions, cell proliferation and migration (12). Injury or diseases of the nervous system lead to alterations in the composition of CSPGs (1). In the previous studies, it was reported that 


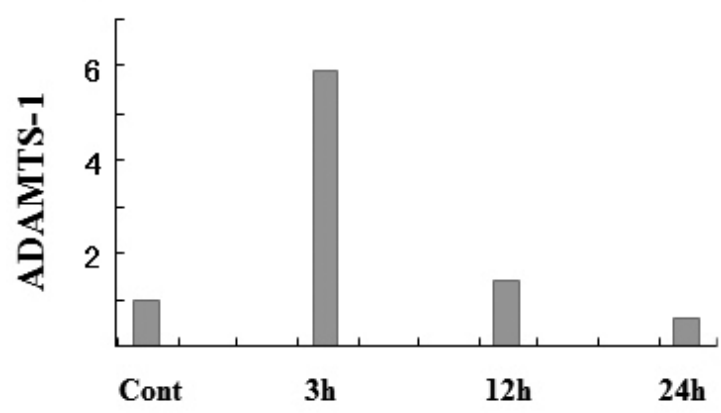

(A)

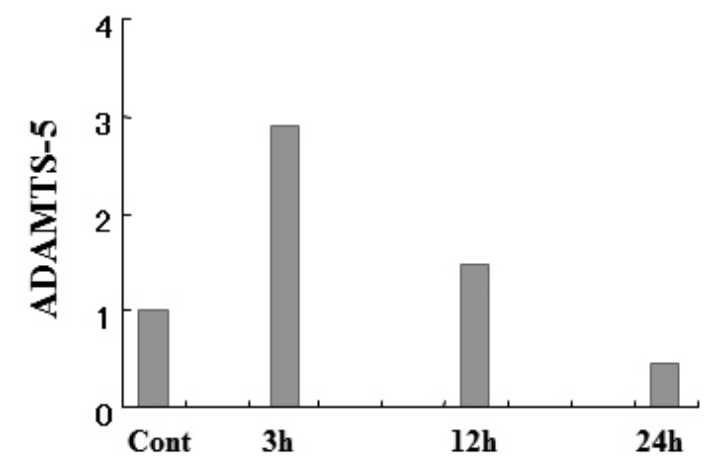

(C)

Figure 1: ADAMTS1, $-4,-5,-9$ expression levels by real time PCR in control and IL-1 $(10 \mathrm{ng} / \mathrm{ml})$ stimulated astrocyte cultures at 3,12 and 24 hours time points.

proteoglycans are upregulated in the parenchymal tissue secondary to injury (20), ending with impeding neurite outgrowth, axonal regeneration and remyelination. In an experimental study, Bradbury et al. reported that following spinal cord injury, eliminating proteoglicans promotes axonal regrowth and ameliorates functional recovery (3).

All these debilitating process lead to activate the degradation of extracellular matrix molecules. Metalloproteinases including MMPs, ADAMs, and ADAM-TS play a key role in proteolytic degradation (13). Many diseases such as cancer, injury, arthritis, arteriosclerosis and tumor metastasis regulate the secretion of these metalloproteinases.

The ADAMTSs are a subgroup of newly identified zinc metalloproteases encoded by 19 different human genes displaying multiple functions including proteolysis, adhesion, cell fusion, signalling as well as extracellular matrix degredation (19). However pathological conditions such as arthritis, malignancies and injuries lead to different expression levels of these proteases. Signal peptide, prodomain, metalloproteinase domain, disintegrin domain, trombospondin type 1 motif, cystein-rich domain and spacer region constitute the domain structure of ADAMTSs. The most

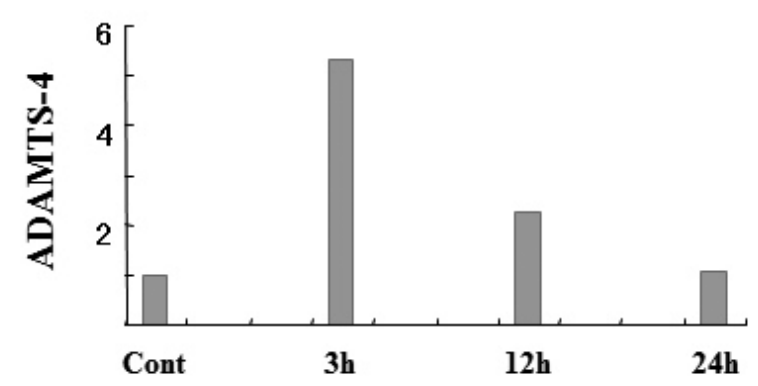

(B)

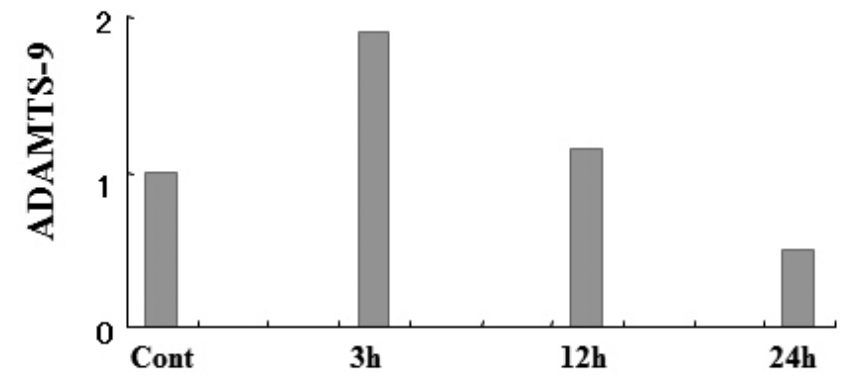

(D) important difference of ADAMTS from ADAM and MMPs is that ADAMTS lack a transmembrane domain so that they are secreted and bind to extracellular matrix with trombospondin type1 motifs and cleave the substrate (15). Varying numbers of trombospondin type 1 motifs are bound to the constant structure at the C-terminal and this specifies the isoforms of ADAMTS (Figure 2, Figure 3). ADAMTS4 and ADAMTS5 cleave aggrecan (the major type of proteoglycan) at the Glu373Ala374 site in the G1 domain, whereas Asn341-Phe342 is the cleavege site of MMPs in the same domain (8) (26).

Among the ADAMTS members, ADAMTS1 and 4 are known to be IL-1-inducible proteases that are upregulated under inflammatory conditions (14). Tortorella et al. demonstrated that ADAMTS 4 expression is upregulated in bovine nasal cartilage in response to IL-1 stimulation (24). Vankemmelbeke et al reported that IL-1 induced expression of ADAMTS4 and -5 in cartilage explant cultures, but failed to alter expression levels of these aggrecanases in the synovium (25). In our recent experimental study we showed that ADAMTS1, -5 and -9 are expressed in spinal cord injured astrocytes (6). However, this is the first experimental design searching the expression levels of ADAMTS1, $-4,5$ and -9 in an astrocyte culture. 


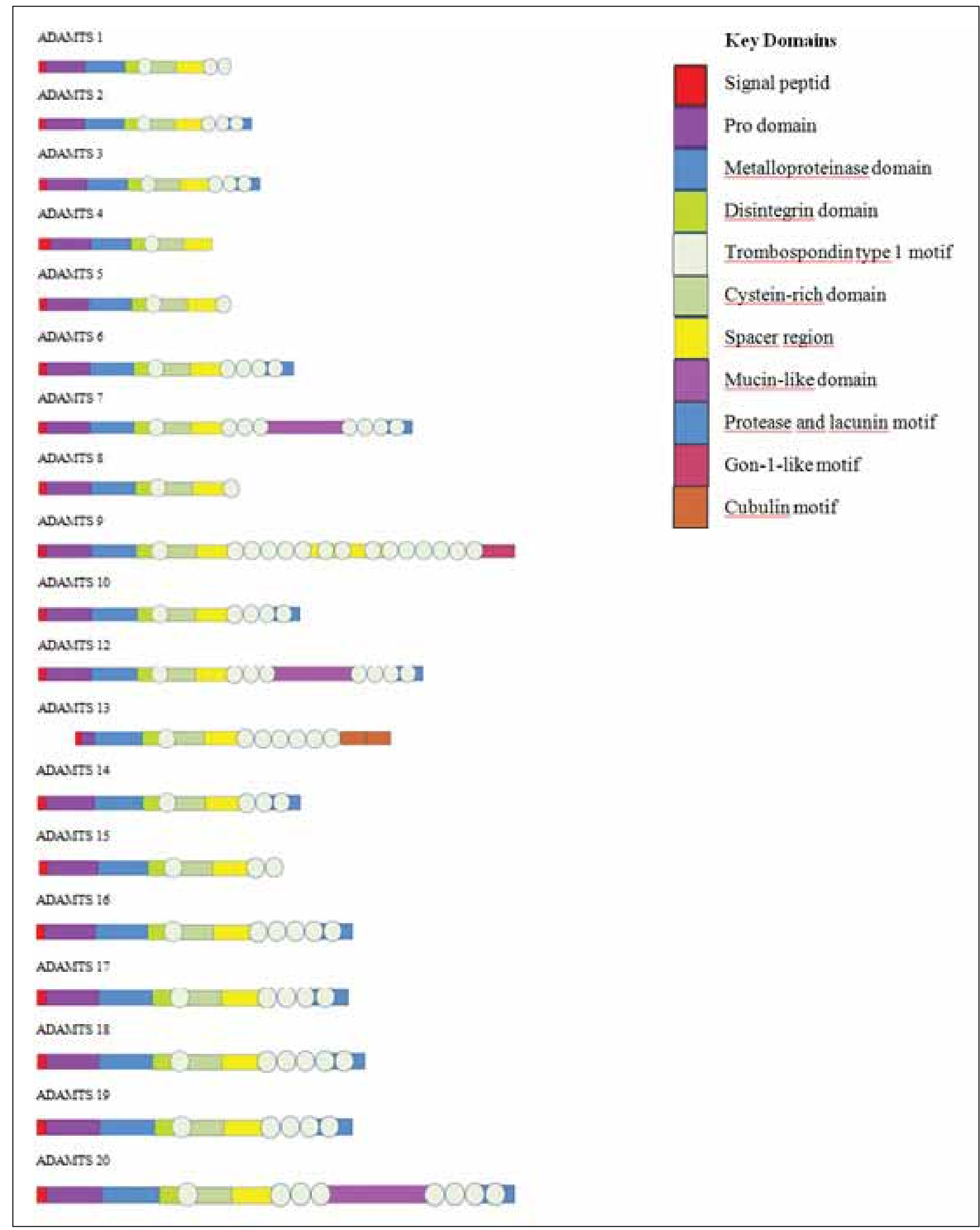

Figure 2: Domain structure of ADAMTS proteins (Key to domains). 


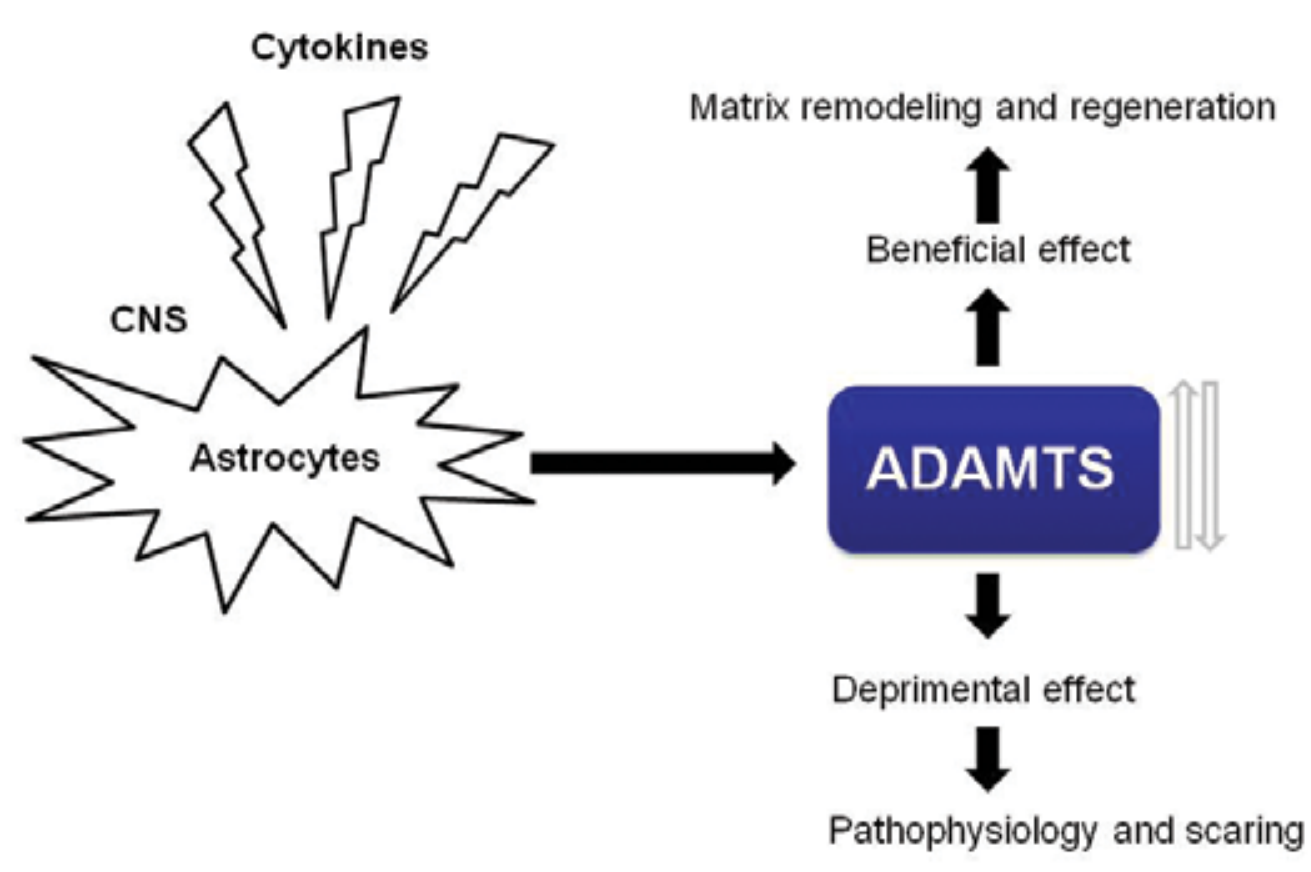

Figure 3: Schematic presentation of our hypothesis and experimental design. Astrocytes in central nervous system (CNS) affected by IL-1 during injury, inflammation and tissue remodeling. Any increase or decrease in ADAMTS may have beneficial or detrimental effects during injury and matrix remodeling. ADAMTS are therefore good candidate genes for CNS disease pathogenesis.

There are some limitations of our study. We sought mouse astrocytes. We do not know whether human astrocytes are induced or not in this experimental design. We also did not check ADAMTS-cleaved aggrecan and versican fragments in the tissues.

In the previous studies, it was demonstrated that CNS injury causes changes in the expression levels of ADAMTS4. Cua et al. compared the effects of MMPs and ADAMT4 on degradation of CSPGs and found that ADAMTS4 overcomes inhibition of axonal regeneration and promotes neurite outgrowth through a proteolytic mechanism (5). Furthermore, Hamel et al. showed that ADAMTS4 increases the neurite outgrowth on rat neuron culture and Haddock found that ADAMTS4 caused a decrease in phosphocan accumulation $(10,11)$. ADAMTS1, -5 and -9 are also known for their ability to cleave aggrecan and versican as aggrecanases (20).

In the present study, we evaluated whether aggrecanases are expressed in cultured astrocytes, and therefore studied the quantitative expression of mRNA for ADAMTS1, $-4,-5$ and -9 in cultured astrocytes. The aim of this study was to test the hypothesis that ADAMTSs mediate IL- 1 stimulated neurotoxicity in the mouse astrocyte and to analyse the levels of ADAMTSs at varying time points. Our data revealed expression of ADAMTS1, $-4,-5$ and -9 in astrocytes. We analyzed the levels at 3, 12 and 24 hours time points by real time PCR. IL1 beta induced the release of astrocytic ADAMTS1, -4, 5 and -9. ADAMTS1, -4 expression showed the highest increase at 3 hours after IL-1 stimulation with respect to the control group, and ADAMTS1 and ADAMTS4 expression were relatively stronger than the increase in ADAMTS5 and -9. The expression levels of ADAMTS1, $-4,-5$, and -9 gradually declined to control levels by 12 and 24 hours.

Overall, our data present a framework for the matrix events in CNS injury. The present findings suggesting that ADAMTS1 and -4 transcription and protein expression are stimulated in astrocyte culture in response to $\mathrm{IL}-1$, indicating that ADAMTS1 and -4 are the essential aggrecanese candidate responsible for the increased proteoglycan degradation in early phase of injury. The results obtained from various experimental studies in the literature lead to chaos about the effect of these metalloproteinases. However, it is obvious that decreased expression levels of especially ADAMTS1 and -4 to control levels by $12 \mathrm{~h}$ does not contribute to preventing the forming of glial scar tissue that may be related to inadequate production of metalloproteinases or overblown accumulation of proteoglycans that block axonal regeneration.

Aggrecanases may play a role in tissue destruction in the progression of CNS injury and they are differentially expressed in mouse CNS, suggesting a crucial role in the pathogenesis of CNS injury. The increased ADAMTS expression in the first three hours, may probably be an assault to minimize the catatrophic effect of cytokine stimulation or it reflects that these proteases are involved in the devastating effect of cytokine secretion. It remains to be determined whether the increase in aggrecanases is beneficial or detrimental to the process of regeneration of function following cytokine stimulation. However, these results are currently the framework and link to ADAMTS proteases' release from the astrocyte. 


\section{REFERENCES}

1. Asher RA, Morgenstern DA, Fidler PS, Adcock KH, Oohira A, Braistead JE, Levine JM, Margolis RU, Rogers JH, Fawcett JW: Neurocan is upregulated in injured brain and in cytokinetreated astrocytes J Neurosci 20:2427-2438, 2000

2. Asher RA, Morgenstern DA, Shearer MC, Adcock KH, Pesheva $P$, Fawcett JW: Versican is upregulated in CNS injury and is a product of oligodendrocyte lineage cells. J Neurosci 22: 2225-2236, 2002

3. Bradbury EJ, Carter LM: Manipulating the glial scar: Condroitinase $A B C$ as a therapy for spinal cord injury. Brain Res Bull 84:306-316, 2011

4. Cauwe B, PE Van den Steen PE, Opdenakker G: The biochemical, biological, and pathological kaleidoscope of cell surface substrates processed by matrix metalloproteinases. Crit Rev Biochem Mol Biol 42:113-185, 2007

5. Cua RC, Lau LW, Keough MB, Midha R, Apte SS, Yong VW: Overcoming neurite-inhibitory chondroitin sulfate proteoglycans in the astrocyte matrix. Glia 61:972-984, 2013

6. Demircan K, Yonezawa T, Takigawa T, Topcu V, Erdogan S, Ucar F, Armutcu F, Yigitoglu MR, Ninomiya Y, Hirohata S: ADAMTS1, ADAMTS5, ADAMTS9 and aggrecanase-generated proteoglycan fragments are induced following spinal cord injury in Mouse. Neurosci Lett 544:25-30, 2013

7. Faulkner JR, Herrmann JE, Woo MJ, Tansey KE, Doan NB, Sofroniew MV: Reactive astrocytes protect tissue and preserve function after spinal cord injury. J Neurosci 24:2143-2215, 2004

8. Gendron C, Kashiwagi M, Lim NH, Enghild JJ, Thøgersen IB, Hughes C, Caterson B, Nagase $\mathrm{H}$ : Proteolytic activities of human ADAMTS-5: Comparative studies with ADAMTS-4. J Biol Chem 282:18294-18306,2007

9. Gilbert RJ, McKeon RJ, Darr A, Calabro A, Hascall VC, Bellamkonda RV: CS-4,6 is differentially upregulated in glial scar and is a potent inhibitor of neurite extension. Mol Cell Neurosci 29:545-558, 2005

10. Haddock G, Cross AK, Plumb J, Surr J, Buttle DJ, Bunning RA, Woodroofe MN: Expression of ADAMTS-1, -4, -5 and TIMP-3 in normal and multiple sclerosis CNS white matter. Mult Scler 12:386-396,2006

11. Hamel MG, Ajmo JM, Leonardo CC, Zuo F, Sandy JD, Gottschall PE: Multimodal signaling by the ADAMTSs (a disintegrin and metalloproteinase with thrombospondin motifs) promotes neurite extension. Exp Neurol 210:428-440, 2008

12. lozzo RV, Schaefer L: Proteoglycans in health and disease: Novel regulatory signaling mechanisms evoked by the small leucine-rich proteoglycans. FEBS J 277:3864-3875

13. Jones GC, Riley GP: Review ADAMTS proteinases: A multidomain, multi-functional family with roles in extracellular matrix turnover and arthritis. Arthritis Res Ther 7:160-169, 2005
14. Kuno K, Kanada N, Nakashima E, Fujiki F, Ichimura F, Matsushima K: Molecular cloning of a gene encoding a new type of metalloproteinase-disintegrin family protein with thrombospondin motifs as an inflammation associated gene. J Biol Chem 272:556-562, 1997

15. Kuno K, Matsushima K: ADAMTS-1 protein anchors at the extracellular matrix through the thrombospondin type I motifs and its spacing region. J Biol Chem 273:13912-13917, 1998

16. Morgenstern DA, Asher RA, Fawcett JW: Chondroitin sulfate proteoglycans in the CNS injury response. Prog Brain Res 137:313-332, 2002

17. Oberheim NA, Wang X, Goldman S, Nedergaard M: Astrocytic complexity distinguishes the human brain. Trends Neurosci 29:547-553, 2006

18. Pekny M, Nilsson M: Astrocyte activation and reactive gliosis. Glia 50:427-434, 2005

19. Porter S, Clark IM, Kevorkian L, Edwards DR: The ADAMTS metalloproteinases. Biochem J 386:15-27, 2005

20. Rauch U: Extracellular matrix components associated with remodeling processes in brain. Cell Mol Life Sci 61: 2031-2044, 2004

21. Silver J, Miller JH: Regeneration beyond the glial scar. Nat Rev Neurosci 5:146-156, 2004

22. Snow DM, Mullins N, Hynds DL: Nervous system-derived chondroitin sulfate proteoglycans regulate growth cone morphology and inhibit neurite outgrowth: A light, epifluorescence, and electron microscopy study Microsc Res Tech 54:273-286, 2001

23. Tate CC, Tate MC, LaPlaca MC: Fibronectin and laminin increase in the mouse brain after controlled cortical impact injury. J Neurotrauma 24:226-230, 2007

24. Tortorella MD Burn TC, Pratta MA, Abbaszade I, Hollis JM, Liu $\mathrm{R}$, Rosenfeld SA, Copeland RA, Decicco CP, Wynn R, Rockwell A, Yang F, Duke JL, Solomon K, George H, Bruckner R, Nagase $\mathrm{H}$, Itoh $\mathrm{Y}$, Ellis DM, Ross $\mathrm{H}$, Wiswall BH, Murphy $\mathrm{K}$, Hillman MC Jr, Hollis GF, Newton RC, Magolda RL, Trzaskos JM, Arner EC: Purification and cloning of aggrecanase-1: A member of the ADAMTS family of proteins. Science 284, 1664-1666,1999

25. Vankemmelbeke MN, Holen I, Wilson AG, Ilic MZ, Handley CJ, Kelner GS, Clark M, Liu C, Maki RA, Burnett D, Buttle DJ: Expression and activity of ADAMTS-5 insynovium. Eur J Biochem 268:1259-1268, 2001

26. Westling J, Fosang AJ, Last K, Thompson VP, Tomkinson KN, Hebert T, McDonagh T, Collins-Racie LA, LaVallie ER, Morris EA, Sandy JD: ADAMTS4 cleaves at the aggrecanase site (Glu373Ala374) and secondarily at the matrix metalloproteinase site (Asn341-Phe342) in the aggrecan interglobular domain. J Biol Chem 277:16059-16066,2002 